\title{
An Examination of Ethical Influences on the Work of Tax Practitioners
}

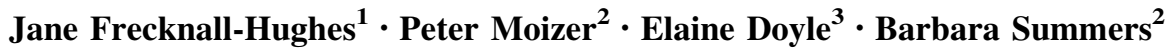

Received: 15 January 2015/ Accepted: 20 January 2016/Published online: 17 February 2016

(c) The Author(s) 2016. This article is published with open access at Springerlink.com

\begin{abstract}
As a contribution to the continuing debate about tax practitioner ethics, this paper explores the main streams of Western ethical thought that are relevant to tax practitioners' work, most typically deontology and consequentialism (although virtue ethics and distributive justice are also considered). It then goes on to consider the impact of such ethical influences on the professional ethical codes of conduct that govern tax practitioners' work (with specific reference to the UK and Ireland), and attempts to unravel the complex work and ethical environment of the practice of tax in terms of tax compliance and tax avoidance. The paper then examines the prior studies on tax practitioners and ethics and the type of dilemmas that practitioners face in the context of their work. The paper proceeds to examine empirically the extent to which tax practitioners take a consequentialist versus a deontological approach in their reasoning about moral dilemmas. This is carried out by an innovative use of the Defining Issues Test.
\end{abstract}

Jane Frecknall-Hughes

J.Frecknall-Hughes@hull.ac.uk

Peter Moizer

pm@lubs.leeds.ac.uk

Elaine Doyle

elaine.doyle@ul.ie

Barbara Summers

bs@lubs.leeds.ac.uk

1 Hull University Business School, Cottingham Road, Hull HU6 7RX, UK

2 Leeds University Business School, University of Leeds, Maurice Keyworth Building, Leeds LS2 9JT, UK

3 Kemmy Business School, University of Limerick, Limerick, Ireland
Keywords Consequentialism $\cdot$ Deontology $\cdot$ Distributive justice · Defining Issues Test (DIT) - Ethical codes - Tax practitioners' work - Tax compliance $\cdot$ Tax planning/ avoidance

\section{Introduction}

There has been a substantial amount of coverage in the international media in recent years alleging that tax practitioners behave unethically. Of particular note are the interrogations of senior members of large accounting and tax firms by the UK government's Public Accounts Committee about the type of advice they provided, in the wake of allegations of aggressive and unethical tax avoidance practices employed by multinational companies such as Amazon, Facebook, Google and Starbucks (see Barford and Holt 2012; Armitstead 2013; Fuller 2013). However, this scrutiny and the level of public interest do not appear to have led to any examination of the ethics underlying the conduct of tax professionals, or how ethics might be operationalised in the practice of tax work. This gives rise to two particular questions, which this paper seeks to address:

1. What is the conceptual framework within which tax practitioners make decisions, and how does this affect the priority given to the different ethical considerations which might influence their decision-making processes?

2. Does the tax context itself have any impact on the type of ethical reasoning used, when compared to a more general social situation?

The paper first addresses these questions by examining the main streams of Western ethical thought that are relevant to tax practitioners' work, primarily deontology and consequentialism, although virtue ethics and distributive 
justice are also considered. It then goes on to consider the impact of such ethical influences on the professional ethical codes of conduct that govern tax practitioners' work, and attempts to unravel the complex work mix and ethical environment of tax work in terms of tax compliance and tax avoidance. The paper then examines the prior studies on tax practitioners and ethics and the type of dilemmas that practitioners face in the context of their work.

The methodology section explains the innovative use of the scenario-based Defining Issues Test (DIT) to obtain empirical data from tax practitioners and a control group of non-tax practitioners on the types of ethical reasoning used in a range of situations. The sample selection and coding of participant responses to identify deontology and consequentialism are then explained. The analysis of the results follows and the final section offers conclusions to the paper, with discussion of the implications of the results.

\section{Ethical Streams of Thought and their Potential Relevance to Tax Practitioners}

\section{Deontology and Consequentialism}

Perhaps the primary theoretical ethical foundations that have relevance to the work of tax practitioners are deontology and consequentialism (though many other ethical theories may also have elements that can be related to tax ethics decisions). Indeed, theories of business ethics such as the Hunt and Vitell model (1993) have long recognised that both deontological (rules based) and practical/utilitarian considerations influence decisions. A deontological approach to ethics assumes that particular aspects of an action determine its moral quality absolutely (Flew 1979; Raphael 1981). It relies on the creation of certain moral injunctions by which an individual can judge whether an action is morally right, for example, 'thou shalt not kill' (as in the Sixth Commandment). Kant (1785, cited in Flew 1979) used the expression "categorical imperative" to provide a test of what is a morally appropriate action: a maxim that should become a universal law. Thus a proposed action could be analysed in terms of its moral character and a decision could be made whether it is morally obligatory or morally wrong on the basis of this analysis alone, without considering any other aspects of the situation. However, even moral imperatives do not apply absolutely, as there are circumstances when killing is deemed appropriate, for example, in war, in self-defence or in defending a third party if under life-threatening attack. In any event, legality and morality need not be coincident, with slavery being an example from history.

The debate between consequentialists and deontologists has often centred on the doctrine of 'the end justifies the means' (a doctrine which teaches that evil means may be employed to produce a good result-see Mackie 1986, pp. 154-155). However, such a doctrine is an extreme (and oversimplified) version of consequentialism, because it implies that the moral difference between ends and means is such that only the end is important, the means to achieve it having no moral significance at all. The more usual consequentialist view is that there is no morally relevant distinction between means and ends and hence that any badness in the proposed means has to be balanced fairly against the expected goodness of the end. It is therefore possible to justify the use of evil means to achieve a good end, provided that the end is a sufficiently good outcome to outweigh any bad outcomes created by the means. As actions are judged in terms of the consequences that result, any form of consequentialism locates ethical value ultimately in states of affairs (Williams 1985, p. 77). Consequentialism can be more precisely formulated, for example, by identifying specific groups of people affected by particular outcomes. These might range from the individual (egoism) to everyone bar the individual (altruism).

A particular form of consequentialism is utilitarianism, whereby actions are judged not only by their consequences but also by the amount of benefits everyone concerned derives from those consequences. The aim is the greatest happiness of the greatest number. ${ }^{1}$

In terms of tax practitioners and their decision-making processes, in an ideal world, a practitioner acting ethically should follow not only the letter of the law, but also its spirit (underlying intention). In an ideal world also, the letter of the law and its underlying spirit would be aligned with one another, but this is not always the case in reality. The intention, or spirit, of the law may be unclear in terms of what it is trying to do or to what or whom it applies. For example, an online version of HMRC's International Tax Handbook in 2007 stated:

...[T]he expression 'tax planning'...embraces a wide range of options from those which are merely

\footnotetext{
${ }^{1}$ In recent years, the theory has been subdivided into two variants: act utilitarianism and rule utilitarianism. Act utilitarianism holds that where an agent has a choice between courses of action (or inaction), the right act is that which will produce the most happiness, not just for the agent, but for all who are in any way affected (see Mackie 1986).

Rule utilitarianism is not concerned with assessing individual acts, but considers the utility of a rule for various types of action. The idea is to undertake the course of action that would be prescribed by an optimum set of rules, even if on a particular occasion less than total happiness would result. Thus, where the act utilitarianism would ask, "what will be the outcome of my doing that?", the rule utilitarianism's question would be, "what if everyone did that?" (Flew 1979, p. 361). Rule utilitarians could also be prepared to argue that it is for the best for individuals to adopt strict rules and not to deviate in particular circumstances, even when in those particular circumstances more goodwill would result from deviance from the rules.
} 
'mitigatory' to those which we would regard as 'avoidance'...[F]ine distinctions between 'tax planning' and 'tax avoidance' are seen as being of less consequence than the overall effect on the yield to the Exchequer. This is particularly so where the apparent result is not in accordance with Parliament's intentions or which would not have been had Parliament addressed itself to the particular issue.

There remains considerable debate about what the spirit of the law actually is. As Freedman (2012, pp. 635-636) notes:

If by "spirit of the law" is meant simply the proper intention of the legislature as discovered by the application of permissible purposive construction, then of course the courts should be finding the spirit of the law and the taxpayer should be abiding by this. But others suggest that the spirit of the law may be found outside the decision of the courts, in terms of what is acceptable to the revenue authorities or current government, or perhaps even non-governmental organisations. This means that there may be a gap between the quite proper interpretation given by the courts (based on the limitations of the system, on language and on the legislative process) and the view of the current revenue authorities on the meaning and intent of the law.

Thus a tax practitioner wanting to comply with both the letter and spirit of the law may be confounded by the need to interpret what he/she should do or report, and may overcompensate by elevating the spirit of the law to something somehow beyond legal compliance, but this is a "vague and unenforceable notion" (Freedman 2012, p. 651). Freedman (2012, p. 629) also warns that the answer does not lie in:

the old cat-and-mouse game of detailed legislation, which often provides opportunities for taxpayers and their advisers to find ways of subverting that very legislation - the game of 'creative compliance'.

Less detailed legislation which allows for the exercise of some discretion (guided by defined principles) may have the result of aligning the letter of the law better with its spirit (see Freedman 2012, p. 629 and 656), but this is a balance that is difficult to strike, even where language seems unequivocal and clearly deontological. For example, the Tenth Commandment, which forbids the coveting of a neighbour's house, wife, ox and ass and anything that belongs to a neighbour might seem to have addressed everything to which an unjust desire to acquire might extend. 'Anything' might reasonably be interpreted as the type of possessions not envisaged at the time of Moses, for example, an iPad or a mobile phone. Ironically, however, 'anything' might also be interpreted as the same kind of item as in the list preceding (e.g. people or livestock), and thus not extend to things that could not have been envisaged at the time.

Additional influences upon private sector tax practitioners provide different elements which can affect their moral stance. Unlike a medical practitioner, whose duty is solely the well-being of a patient, private sector tax practitioners are subject to different kinds of moral suasion. In the first instance, a duty will be owed to their clients (Hammer 1996; Jackson and Milliron 1989), but tax practitioners have been considered as serving taxpayers and the government- thus acting as advocates for their clients at the same time as serving as intermediaries in the tax system (Brody and Masselli 1996; Duncan et al. 1989; Yetmar and Eastman 2000). A role with multiple facets creates greater ethical complexity. Tax practitioners thus have a duty not only to their clients, but also to the government, their firm, their profession, the wider public and of course, to themselves. The view of practitioners as government representatives may derive from the fact that technically competent practitioners will consider the stance a taxing authority may take, especially where ambiguous or disputed items are under consideration. Hence teleological considerations have a part to play. This may also be true for a medical practitioner in terms of a patient's well-being. For instance, if several different drugs may possibly be used to save a patient's life, each with different costs, would the medical practitioner need to consider the individual cost of each of them and weigh one against the other before deciding-especially when, as in the UK, the patient care may be being provided by the National Health Service, which is funded out of tax revenue? In terms of tax, the types of work a tax practitioner does may also be influential, and we discuss this issue later.

\section{Other Ethical Streams of Thought}

Other streams of thought that have some relevance to tax practitioners' decision making are virtue ethics and distributive justice/entitlement theory, which will be discussed here briefly.

"Virtue ethics is character-based" (Athanassoulis 2014), which means that an act considered 'right' would depend on the individual character of the decision maker as a virtuous person. However, there are long established problems in determining what a virtue is, in defining a virtuous person and in the fact that different virtues might conflict so as to produce a moral dilemma.

For example, should a compassionate person consider lying to someone so as not to tell them a hurtful or damaging truth? This would violate honesty (for example) as a 
virtue. It is also impossible to tell from a particular action whether a given individual was inherently moral or was behaving in a moral way because of other considerations: a person might tell the truth to a tax authority, not because he/she was an innately truthful person, but because it might actually attract more clients and thus make business more profitable.

Tax practitioners' moral choices could also be influenced by a wider view of how they feel that resources generally should be distributed within society, and of the role of government. Taxation is used by governments for many purposes, including raising monies to fund government expenditure, controlling the economy of the country and redistributing wealth. All forms of taxation involve taking money away from individuals and their attitude to giving money to the State will be determined in part by their view of the legitimacy of the taxation process, as, of course, not all things that are legal are moral. When slavery was permitted by law, many people did not agree with it. Moral objections to taxation, even when legally imposed, have contributed to a number of rebellions and revolutions, the American War of Independence and the French Revolution being very well known examples.

Important to beliefs about the legitimacy of the tax process will be a notion of distributive justice, that is, whether distribution of goods among members of society is deemed 'acceptable' (that is, the majority would accept it). This is a philosophical stance particularly associated with the work of John Rawls (see also Lamont and Favor 2013). If tax practitioners did not think that a distribution was acceptable, they might be impelled to work towards changing it, which might result in the adoption of a consequentialist frame of working in regard to themselves and their clients.

The simplest principle of distributive justice would be that of strict or radical equality: every person should have the same level of material goods and services. There are two main criticisms of strict equality distributions: (i) everyone can be materially better off if incomes are not strictly equal (Difference Principle) — that is, the possibility of earning greater income will bring forth greater productive effort (see Rawls 1971, p. 302); and (ii) strict equality rules do not maximise the collective utility (utilitarianism).

Nozick (1974) expanded the concept of distributive justice in the form of entitlement theory which proposes that a distribution is just if everyone is entitled to the holdings they possess under the distribution. This inherently supports the right to own (varying amounts of) personal property, which ultimately derives from the philosophy of John Locke. There are two aspects of a person's holdings: original acquisition of holdings and transfer of holdings. Given that there are now very few unheld things, individuals acquire holdings mainly as a result of transfers and so there is then the question of whether a transfer is just (i.e. chosen or agreed to by both parties, by means of sales, gifts, profits made, etc.). Given that unjust transfers (e.g. by theft) take place, the principle of rectification, as advanced by Nozick, uses subjunctive information to indicate what would have occurred if the unjust acquisition or unjust transfer had not taken place. According to Nozick, the only just transfer is a voluntary one.

Taxing one person's income so that monies can be used for defence or given to the poor is an example of a transfer determined by the government, but it does not fit the principle of a just transfer unless the individual making the payment does so by choice. However, this is at odds with the concept of the social contract, whereby the willingness to pay tax is seen as a voluntary alienation of one's property rights (see Locke 1690, II.11.140). "Therefore an individual living in a community has, by his decision to live in that community, given consent to paying tax to pay for the benefits he derives" (Frecknall-Hughes 2014, p. 91). However, if citizens felt that they had not given consent, because, for example, tax rates had been arbitrarily raised or tax monies were being spent for purposes with which they disagreed, they might then feel that measures to avoid tax were justified - and so might seek out a tax practitioner with similar views. It is evident that individuals may feel that being asked to pay tax is an unjust transfer. This is supported by empirical studies examining taxpayer attitudes and behaviour (see, for example, Ballas and Tsoukas 1998; Erard and Feinstein 1994; McGee and LaTour 1991). Hence if the citizen regards the taxation system as unjust in the sense that it involves an unjust transfer of his or her resources to others, then the entitlement theory of distributive justice would justify the moral position of the individual, and thus, possibly, the moral position of a like-minded tax practitioner, particularly in the area of tax avoidance, which is considered later.

\section{The Dominance of Deontology}

Deontology has been the driving force behind most codes of conduct for professional tax practitioners. For example, in terms of the UK:

A member is required to serve his client with professional competence and due care within the scope of his engagement letter. The recent public debate on tax avoidance has not changed the member's responsibility to his client. This has been highlighted in the debate surrounding Mehjoo v Harben Barker (a firm) and another company [2013] EWHC 1500 (QB).

Chartered Institute of Taxation (CIOT) (2014, p. 38, Sect. 8.10)

As the above shows, rules tend to be phrased as a series of duties that are morally obligatory for members of the profession, which has always been the case (see Harwood 
1996; Barbour and McDougall 1997). This is the case for other professional bodies whose members undertake tax work, such as the five other institutes in the UK. ${ }^{2}$ The Irish Tax Institute's Code of conduct (2014) is equally prescriptive in terms of integrity and objectivity as the CIOT's, but does not contain the same level of detailed guidance about tax avoidance. However, this is not unexpected as Ireland has had a General Anti-Avoidance Rule since 1989, so is a stage further on than the UK in that principles concerning tax avoidance have been embedded in law. The UK has only relatively recently implemented a General Anti-Abuse Rule, and it remains unclear as to how this will work and how effective it will be, but it is different in concept from a General Anti-Avoidance Rule, as it attempts to define boundaries in terms of acceptable and unacceptable practice, so does not supersede professional ethics codes. However, the first case brought under the Irish GAAR, the O'Flynn case (decided in 2011 by the Irish Supreme Court), demonstrates that the same ethical issues apply as in the UK. The language used seems therefore to frame avoidance in deontological terms, as in the UK. However, as mentioned previously, consequentialism may be relevant also in the area of avoidance.

Importantly, it should be noted, however, that not all tax practitioners will abide by professional codes of ethics as they will not belong to professional bodies. The tax profession is very fragmented, with tax advice being "given by a broad range of business professionals, including accountants, solicitors, barristers, payroll agents, former and current members of government revenue authorities, and tax experts working within industry" (Frecknall-Hughes and McKerchar 2013, p. 422; see also Frecknall-Hughes and Moizer 2015). Virtually anyone can act as a tax practitioner-a situation which prevails in many countries (see Levy 2015), although there is, increasingly, regulation being implemented, but with varying degrees of success, especially in the USA (see Hopkins 2014). Levy (2015, pp. 438-439) comments:

Of the 142 million individual income tax returns filed in 2011,79 million were completed by paid preparers, and a majority of those, 42 million, were filled out by preparers who were neither licensed nor regulated. With few-if any-barriers to entry, the field of tax preparation has drawn unscrupulous players.

\footnotetext{
${ }^{2}$ The Association of Chartered Certified Accountants (ACCA), the Association of Taxation Technicians (ATT), the Institute of Chartered Accountants in England and Wales (ICAEW), the Institute of Chartered Accountants of Scotland, and the Society of Trust and Estate Practitioners (STEP). Members of these bodies often carry out tax work and they may or may not also be members of the Chartered Institute of Taxation.
}

Levy (2015, p. 439) also comments that such tax practice exploits those who are in poor financial circumstances and is accompanied by fraud and incompetence. Brock and Russell (2015) also make the point that highly trained tax professionals, who would actually be members of professional institutes, use their skills to exploit the letter of the law to produce abusive avoidance schemes, suggesting (on p. 7) that they step outside existing "accepted standards of professional integrity" to do so and contribute to institution corruption and fraud, a point also made by Benshalom (2014). In this context, examining the different kinds of work that tax practitioners undertake is helpful in shedding light on the various kinds of dilemmas which can arise and the attendant ethical implications.

\section{An Analysis of the Work of Tax Practitioners}

Much of the criticism levelled at tax practitioners has been in relation to their advice to clients on tax avoidance, but this is only one aspect of their work. However, differences in types of work will result in different thinking, decision processes and ethical implications. Frecknall-Hughes and Moizer (2015) divide the service provided by tax practitioners into two kinds: tax compliance and tax planning/ avoidance advice.

Tax compliance work typically involves the preparation of tax computations for submission on the taxpayer's behalf to the relevant tax authority, and dealing with and resolving any subsequent queries and uncertainties. It involves reporting the economic events that have taken place, with the tax practitioner aiming to ensure that the reporting complies with tax statute. While tax legislation may contain 'grey' areas of unclear law, sometimes it is the situation to which the legislation is applied that is ambiguous. For example, tax statute is clear on the different treatment of repairs from capital expenditure, but in practice the distinction may not be wholly clear. For instance, is a new chimney on a building a new capital item or a repair? The answer will depend on circumstances and on an opinion about what was actually done, so the tax professional may have to make a judgement about how to present information. Moreover, there will inevitably be areas where the figures to be entered in the tax returns are inherently uncertain and need to be negotiated with the tax authorities, as a normal and legitimate part of the process (e.g. determining the value of private company shares or real estate).

Tax planning/avoidance (or mitigation) work occurs when the tax practitioner attempts to devise ways of reducing the taxpayer's liability. In some cases this is noncontentious and is in accordance with both the letter and spirit of the law, such as devolving estates under UK 
inheritance tax law by making lifetime transfers (non-taxable if made seven years prior to death).

It is also possible, however, for tax practitioners to go further and deliberately test or stretch a tax statute which is unclear or ambiguously written, such that one or more interpretations may be attempted, or where issues arise which are not the subject of specific statute or case law precedent. Such testing or stretching is at the outer extremes of tax planning, and commonly involves the establishment of complex or artificial schemes specifically framed with no other aim than to avoid tax. Such 'financial' engineering schemes have come not infrequently to the Courts for a decision as to their legitimacy, as indicated by a large number of well known cases such as Ayrshire Pullman Motor Services and D.M. Ritchie v CIR, IRC v Duke of Westminster, Ramsay (WT) Ltd v CIR, etc., with legal success sometimes going to the taxpayer, but at others to HMRC — but all contributing to the change of opinion over time towards tax avoidance (see Wyman 1997; FrecknallHughes 2007), now explicitly reflected in HMRC's published guidance on the recent UK General Anti-Abuse Rule (GAAR) (HMRC 2013, Section B2.1), which rejects the Courts' decisions "in a number of old cases".

While internal UK schemes increasingly are filtered out by the disclosure of tax avoidance scheme rules (DOTAS) introduced in Finance Act 2004, the cases of Starbucks, Amazon, Google and Facebook indicate that schemes at an international level are still an issue, though they should, perhaps, be better designated as 'tax arbitrage', as they are clearly designed to exploit to advantage the distinctions and differentials in treatments and rates between different tax jurisdictions.

While much may be deduced about tax ethics from the decisions in legal cases, those cases themselves offer only occasional comment about the ethical duties of a tax practitioner, which sometimes seems at odds with the legal decisions themselves. For example, in the 1997 case of Hurlingham Estates Ltd $v$ Wilde \& Partners it was inherently suggested (at p. 628) that a solicitor owed a duty to his client to structure a property transaction so as to avoid a tax charge. A similar view prevailed in the long-running case of Mehjoo $v$ Harben Barker, but this was reversed in the final 2014 Court of Appeal judgment, with great significance being placed on the fact that Mr. Mehjoo had "accepted in evidence that he would not have gone ahead with the [scheme] if he had been advised that there was a substantial risk of it being challenged by HMRC" (Rayney 2014); and on the fact that under the terms of its engagement letter, Harben Barker was only obliged to provide limited tax planning advice. Such case comments create a degree of confusion in ethical terms as to what a practitioner's duty is supposed to be-a situation which is open to exploitation by a less scrupulous practitioner who, if not a member of a professional body, would not be bound by any code of professional ethics.

\section{Prior Studies on Tax Practitioners and Ethics}

Prior studies on tax practitioners and ethics rarely define what is meant by 'ethics' in terms of practitioner decision making and behaviour, taking the term to be self-explanatory from the context of the issues examined. It is evident that ethical issues arise across the full spectrum of a practitioner's work, both compliance and avoidance/planning. For example, Longenecker et al. (1989a) surveyed 2156 managerial and professional business personnel to find that respondents under the age of 40 were "significantly more permissive in their views regarding ethics in a variety of situations" (as cited in Stainer et al. 1997, p. 216), including cases of overstating expenses and evading taxes, despite being under no significant pressure to act unethically. Longenecker et al. (1989b), in looking at different ethical behaviour between large and small firms of advisers, found that while small firms tolerated overstatement of expenses, evasion of taxes, collusion in bidding and insider trading more than large firms, they expressed more severe views on issues such as faulty investment advice and misleading financial reporting (again, cited by Stainer et al. 1997, p. 217). Marshall et al. (1998) suggest that in Western Australia the most important ethical issue is a failure to ensure confidentiality in regard to privileged client information, with inadequate technical competence, failure to make reasonable enquiries/conduct research, continuing to act for a client where there is incorrect information and conflicts in distinguishing between tax planning and tax avoidance also emerging as frequent and important issues. Stainer et al. (1997) comment on the empirical studies that have been undertaken in respect of ethical issues in taxation from the standpoint of the tax adviser, generally highlighting the controversial nature of some tax planning/ avoidance practices. The issue of increasingly aggressive tax avoidance (that is, the willingness of tax practitioners to adopt reporting positions or promote avoidance schemes which challenge revenue authorities' own interpretation or application of tax law) over time has become a predominant theme (see, for example, Bandy et al. 1994; Cloyd 1995; Cuccia 1994; Duncan et al. 1989; Jackson et al. 1988; LaRue and Reckers 1989; Reckers et al. 1991; Roberts 1998; Sanders and Wyndelts 1989; and Schisler 1994, 1995) and is now targeted by governments worldwide (see Frecknall-Hughes 2007). While such studies suggest that aggressive tax 
avoidance is unethical, they do not spell out why it is unethical, again, perhaps, assuming that it is self-evident that aggressive tax avoidance results in less tax revenue being collected such that fewer public benefits can be provided, which affects particularly members of society who need those benefits. Brock and Russell's more recent (2015) study is one of the few that identifies the effects of the reduced tax revenue that results from aggressive (or abusive) avoidance, though does not do so within a specifically ethical framework. That tax practitioners do apply a less principled level of reasoning in considering tax dilemmas (as opposed to social dilemmas) is established by Doyle et al. (2013) with little difference made by the size of firm for which they work (Doyle et al. 2014).

While the studies cited above consider ethical issues, they do not consider the underlying ethical framework the practitioners use to formulate their decisions. To the best of our knowledge, only two studies have done this-one by Burns and Kiecker (1995) and a second by Cruz et al. (2000). These two studies, however, while they consider the ethical framework applied, consider it from particular perspectives. Burns and Kiecker (1995) consider tax supervisors reprimanding non-ethical behaviour from the standpoints of deontology and utilitarianism, while Cruz et al. (2000) look at hypothetical cases involving client pressure to adopt aggressive reporting positions, and the extent to which practitioners' responses could be measured using the multidimentional ethics scale (MES) as consistent with five ethical philosophies (moral equity, contractualism, utilitarianism, relativism and egoism). They found that practitioners' ethical judgements and self-reported behavioural intensions were primarily affected by the moral equity and contractualism dimensions of the MES while failing to observe a consistent relationship between the utilitarianism dimension and either ethical judgements or behavioural intentions. ${ }^{3}$ A study by Greenfield et al. (2007) also considers how the ethical orientation of tax practitioners in terms of idealism and relativism affects professional commitment.

\section{Research Approach}

The ethical stance adopted by a tax practitioner is therefore likely to be a complex balance between personal characteristics (where virtue ethics is relevant); the extent to which his/her personal view of the law is informed by the

\footnotetext{
${ }^{3}$ Contractualism is a deontological philosophy reflecting the extent to which a given behaviour violates individual duties and obligations. Egoism judges actions based on the promotion of individual selfinterest (egoism). Utilitarianism has already been discussed. However the other two philosophies (moral equity and relativism) are less easily categorised.
}

fairness of the distribution of resources within society (distributive justice/entitlement theory); interpretation of the law, especially of whether the letter and spirit of the law are aligned and whether this can be exploited; the persons or bodies to whom a duty is perceived as owed (client, firm, self, government, society); the fragmentation of the profession and whether he/she is subject to a professional code; and the types of tax work done. However, within these considerations, deontological and consequentialist ideas tend to predominate, as our previous discussions have shown. This leads to a refinement of the research questions posed earlier.

1. What is the conceptual framework within which tax practitioners make decisions, and how does this affect the priority given to the different ethical considerations which might influence their decision-making processes? If codes have an effect, would a deontological stance be expected to be more prevalent?

2. Does the tax context itself have any impact on the type of ethical reasoning used, when compared to a more general social situation? Is the balance between deontological versus consequentialist reasoning different in a tax context from a social context? (If professional training and engagement with professional codes affect reasoning in the tax domain, we should see different responses for tax practitioners and non-specialists in this context.)

The empirical testing done here thus aims to identify the extent to which tax practitioners take a consequentialist versus a deontological approach in their reasoning about moral dilemmas in the tax domain. This will be compared with their reaction to moral dilemmas in the social domain to investigate the impact of context. A control group of nonspecialists (ordinary people, with no professional involvement in taxation) from the same jurisdiction as the practitioner participants will also be used in the analysis of both domains to establish the extent to which involvement in the tax profession might influence reasoning. The use of a control group is important in separating the characteristics of the individual from those of the context, and allows us to identify whether individuals in their professional context behave differently from those with no professional involvement. Many earlier studies using the DIT have not included control groups of non-specialists (see Doyle et al. 2013), so the cause of any differences is ambiguous, as the lack of a control group leaves unclear the issue of whether this is an effect of the context or the individual's role in that context.

Participants' responses to moral dilemmas in a social context were collected using the DIT (Rest 1979a), and in a tax context using a tax-specific version of the DIT, the TPDIT, the development of which is described in Doyle et al. (2009). The following sections provide details of 
Table 1 Six stages of moral reasoning

\begin{tabular}{|c|c|c|}
\hline \multirow[t]{2}{*}{ Pre-conventional: focuses on the individual } & Stage one & The morality of obedience: do what you are told \\
\hline & Stage two & The morality of instrumental egoism and simple exchange: let's make a deal \\
\hline \multirow[t]{2}{*}{$\begin{array}{l}\text { Conventional: focuses on the group and } \\
\text { relationships }\end{array}$} & Stage three & $\begin{array}{l}\text { The morality of interpersonal concordance: be considerate, nice and kind: } \\
\text { you'll make friends }\end{array}$ \\
\hline & Stage four & $\begin{array}{l}\text { The morality of law and duty to the social order: everyone in society is } \\
\text { obligated to and protected by the law }\end{array}$ \\
\hline \multirow[t]{2}{*}{$\begin{array}{l}\text { Post-conventional: focuses on the inner self } \\
\text { and personally held principles }\end{array}$} & Stage five & $\begin{array}{l}\text { The morality of consensus-building procedures: you are obligated by the } \\
\text { arrangements that are agreed to by due process procedures }\end{array}$ \\
\hline & Stage six & $\begin{array}{l}\text { The morality of non-arbitrary social cooperation: morality is defined by how } \\
\text { rational and impartial people would ideally organise cooperation }\end{array}$ \\
\hline
\end{tabular}

Adapted from Rest (1994)

these tests and their use in identifying deontological and consequentialist approaches to dilemmas.

\section{Moral Reasoning and the Defining Issues Test}

Cognitive developmental psychologists believe that before an individual reaches a decision about how and whether to behave ethically in a specific situation, ethical or moral reasoning takes place at a cognitive level. The psychology of moral reasoning aims to understand how people think about moral dilemmas and the processes they use in approaching them (Kohlberg 1973; Rest 1979b).

Rest (1979a) developed the DIT to measure moral reasoning using social context dilemmas. It is a self-administered, multiple-choice instrument. Rest (1979b) developed the instrument based on an interpretation of the stages in Kohlberg's stage-sequence theory (see Table 1 above). The test measures the comprehension and preference for the principled level of reasoning (Rest et al. 1999). For more detail on Kohlberg's stage-sequence theory and the DIT, see Doyle et al. (2009).

Data for this study come from a $2 \times 2$ quasi-experimental design comparing the moral reasoning of tax practitioners with that of non-specialists in the context of social- and tax-based ethical dilemmas, as indicated above. For this study we focus on the extent to which participants see consequentialist versus deontological issues as important in considering what action to take in the dilemma scenarios. The test of reasoning in social dilemmas uses the short-form (three scenario) DIT. Participants taking this test are presented with three ethical dilemmas stated in third-person form. They are asked to say what they think the actor in the situation described should do (with an option to say they cannot decide) and then asked to rate the importance of 12 considerations relating to the dilemma, indicating how important each is (in their opinion) in making the decision described. The 12 considerations link to the stages of cognitive moral development described in Table 1, and include a mix of consequentialist and deontological items. The participant is then asked to select the four considerations that he/she considers to be of most importance and to rank these in order. The first of the DIT scenarios, 'Heinz and the Drug', is set out in Appendix 1 as an example. The measure most commonly reported from the test is known as the ' $\mathrm{P}$ ' score (standing for 'principled moral thinking') and is generated from the four most important considerations chosen by the participant (Rest 1994). A higher P score implies more reasoning at the principled level and a lower percentage of reasoning at lower levels. For the analysis here, however, the focus of interest is on the ratings given to each of the 12 considerations, and whether consequentialist or deontological considerations are more highly rated.

For the tax context, we use a tax-specific version of the DIT, the TPDIT, which uses three tax context-specific scenarios. The development of the TPDIT is described in Doyle et al. (2009). The TPDIT was developed to preserve the psychometric characteristics of the original test and to match it as closely as possible to the three scenario version of the DIT. The difference in the TPDIT, as compared with the DIT, lies in the nature of the dilemmas presented to participants and the related 'items for consideration' following each dilemma, all of which are tax practice related. An example of one of the dilemmas included in the TPDIT is set out in Appendix 2.

Participants completed the DIT and TPDIT in a single instrument, with two counterbalanced versions being used to identify and control for any order effects. The order of individual scenarios within the DIT and TPDIT was not varied, in line with practice for the DIT. Both versions 
contained a demographic questionnaire at the end, to collect data about participants' level of education, gender, age and for practitioner participants, their number of years' experience working in tax.

\section{The Sample}

The data for this study were taken from a study of tax practitioners' moral reasoning, some findings from which have been published in Doyle et al. $(2013,2014)$. The previously published findings were based on the P-Scores for participants. The research instrument was administered to 384 practitioners and 306 non-specialists in Ireland using a combination of random, convenience and snowball sampling techniques. The practitioners worked in a range of tax-related roles in Ireland, including private practice and the revenue authority. The non-specialist sample had no professional involvement in taxation. There was a $39 \%$ response rate from tax practitioners (150 completed instruments) and a $45 \%$ response rate from non-specialists (137 completed instruments). Following checks for full completion of the scenario-based questions and the subject reliability checks described in the DIT manual (Rest 1986a), a sample of 201 instruments was available for analysis (tax practitioners $n=101$ and non-specialists $n=100)$.

\section{Coding of the Considerations}

The items for consideration in the DIT and TPDIT were examined and classified as deontological or consequentialist. The DIT, and the TPDIT which followed the DIT format as closely as possible, contain $\mathrm{M}$ items (deliberately written to be pretentious and meaningless) and A items (focusing on taking an anti-authoritarian stance), and these were excluded from the analysis. Eighteen consequentialist items were identified on the DIT and 17 on the TPDIT, and 12 items were identified as deontological on the DIT with 13 on the TPDIT. This is a high degree of balance between the two instruments, given that items were developed to reflect levels of moral reasoning rather than the consequentialist/deontological split. The coding was done by the authors independently of one another on three occasions, each separated by a substantial period of time and the results were then compared and discussed to reach a consensus on the eventual coding used.

To check the coding we examined the relationship between the ratings given to consequentialist and deontological items for consideration and the action the participant chose. Participants taking the DIT/TPDIT are asked to indicate whether the actor in the scenario should take a particular action in the moral dilemma posed (for example, in 'Heinz and the Drug', whether Heinz should steal the drug). Both instruments contain one situation where the 'should' option is clearly consequentialist and one where it is clearly deontological. These unambiguous scenarios were used to check the coding of items. The other two scenarios have some ambiguity in that, for example, in the TPDIT scenario tax avoidance is involved (relating to the promotion/use of a tax avoidance product) and the deontological response would depend on whether the participant feels that what is right is defined by 'you must follow the law' or by 'you must follow the spirit of the law'. These scenarios were therefore not used in the coding check.

To test the coding of deontological and consequentialist items, a MANOVA analysis of each unambiguous scenario was undertaken to check that giving a higher importance rating to deontological items and a lower importance rating to consequentialist items was significantly related to the deontological choice of action (and vice versa for consequentialist choices). Results confirmed the coding with $p<0.05$ for both deontological and consequentialist items in all four scenarios. The coding of items in the 'Heinz and the Drug' scenario is given as an example in Appendix 1.

Separate overall scores for ratings of the consequentialist and deontological items were produced for both the DIT and TPDIT. As the number of items differs across classifications and across instruments, the raw scores were divided by the number of items in each case to give average scores for each participant (DIT consequentialist, DIT deontological, TPDIT consequentialist, TPDIT deontological). The original instruments score the importance of items from 1 (Great Importance) to 5 (No Importance). These were re-coded to reverse the sense of the scale to make the results of the analysis easier to follow (new coding: 1 No Importance; 5 Great Importance).

\section{Analysis and Results}

Descriptive statistics for the average rating given to consequentialist and deontological items in the DIT and TPDIT by the two groups of participants are shown in Table 2 below.

An analysis of the data was undertaken with a GLM Repeated Measures analysis, with the nested repeated measures; consequentialist/deontological (CONSDEONT) and within this social versus tax context (CONTEXT). 
Table 2 Descriptive statistics for the average rating given to consequentialist and deontological items in the DIT and TPDIT by the two groups of participants (non-specialists and tax practitioners)

\begin{tabular}{lll}
\hline & Mean & SD \\
\hline Non-specialists & & \\
DIT & & \\
$\quad$ Consequentialist item ratings & 3.4122 & 0.46529 \\
$\quad$ Deontological item ratings & 3.43 & 0.48515 \\
TPDIT & & \\
$\quad$ Consequentialist item ratings & 2.8888 & 0.57452 \\
$\quad$ Deontological item ratings & 3.7246 & 0.59325 \\
Tax practitioners & & \\
DIT & & \\
$\quad$ Consequentialist item ratings & 3.313 & 0.4533 \\
$\quad$ Deontological item ratings & 3.3383 & 0.49914 \\
TPDIT & & \\
$\quad$ Consequentialist item ratings & 2.576 & 0.54419 \\
$\quad$ Deontological item ratings & 3.5316 & 0.49015 \\
\hline
\end{tabular}

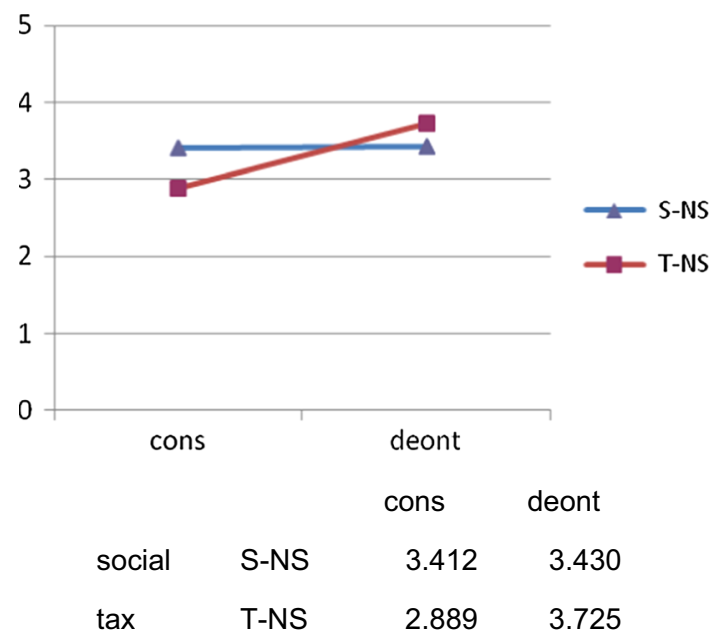

Fig. 1 Average ratings given to consequentialist and deontological items by non-specialists in the social and tax scenarios (mean values shown beneath interaction graph)

TAXPRACTITIONER was included as a between-subjects measure. The intuition of the results can be seen in the interaction graphs below (Figs. 1, 2), and statistical results are given in Table 3 .

As can be seen, the pattern of response in the social and tax scenarios is similar for non-specialists and tax practitioners. In both cases the average ratings of importance for

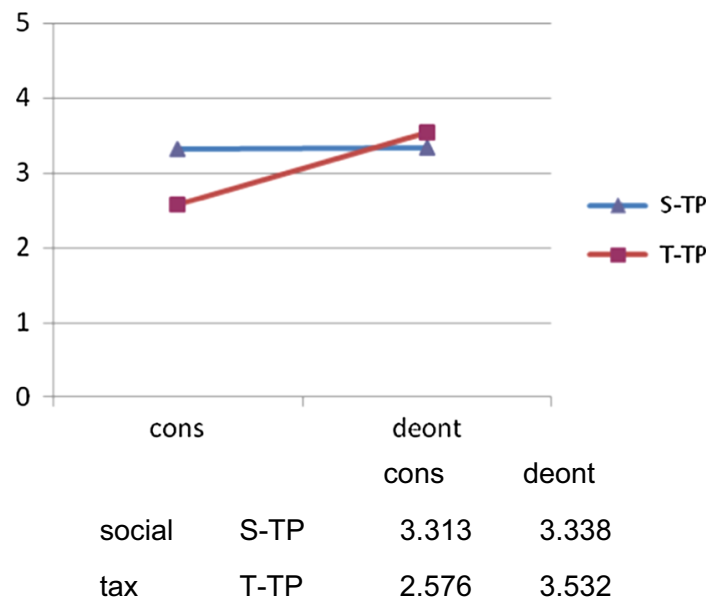

Fig. 2 Average ratings given to consequentialist and deontological items by tax practitioners in the social and tax scenarios (mean values shown beneath interaction graph)

consequentialist and deontological items are similar in the social scenarios. However, in the tax scenarios the average ratings of importance for consequentialist items are lower and those for deontological items are higher. If the two figures are merged, as shown in Fig. 3, it can be seen that the non-specialists' average rating for both types of item is higher than those of the tax specialists in both types of scenario, although the size of the difference is considerably smaller in the social scenarios.

The results show statistically significant effects on rating for whether the item rated is consequentialist or deontological, the context in which the rating is given, and the interaction between these. Robustness checks confirm that these findings are also significant for each group of participants considered separately. Although there are statistically significant effects for whether the participant is a tax practitioner or a non-specialist and the interaction between this and the context, these have a considerably smaller effect size than the variables above.

The ratio of the rating given to consequentialist and deontological items in both instruments was calculated. The measure gives us an indication of the balance of ratings given to consequentialist and deontological items by individuals. If individuals gave the same average rating to both types of item the ratio would be 1 ; if the consequentialist items were given a higher average rating the ratio would be greater than 1 ; if deontological items were given a higher average rating the ratio would be below 1. For both groups of participants the ratio is close to 1 in the social context, but below 1 in the tax context, 
Table 3 GLM repeated measures model looking at the impact on importance rating of whether the item rated is consequentialist or deontological, whether the context is social or tax related and whether the participant is a tax practitioner or non-specialist

\begin{tabular}{lcrrrr}
\hline & Type III sum of squares & df & $F$ & Sig & Effect size (partial $\eta^{2}$ ) \\
\hline Within-subjects effects and interactions & & & & & \\
Consequentialist/deontological (CONSDEONT) & 42.275 & 1 & 139.397 & 0.000 & $0.412^{* * *}$ \\
Context (CONTEXT) & 7.495 & 1 & 63.943 & 0.000 & $0.243^{* * *}$ \\
CONSDEONT $\times$ CONTEXT & 38.398 & 1 & 325.668 & 0.000 & $0.621^{* * *}$ \\
Between-subjects effects and interactions & & & & \\
TAXPRACTITIONER & 6.099 & 1 & 11.646 & 0.001 & $0.055^{* * *}$ \\
CONSDEONT $\times$ TAXPRACTITIONER & 0.204 & 1 & 0.672 & 0.413 & 0.003 \\
CONTEXT $\times$ TAXPRACTITIONER & 1.245 & 1 & 10.625 & 0.001 & $0.051^{* * *}$ \\
\hline
\end{tabular}

Significance levels: $* * * \leq 0.01$

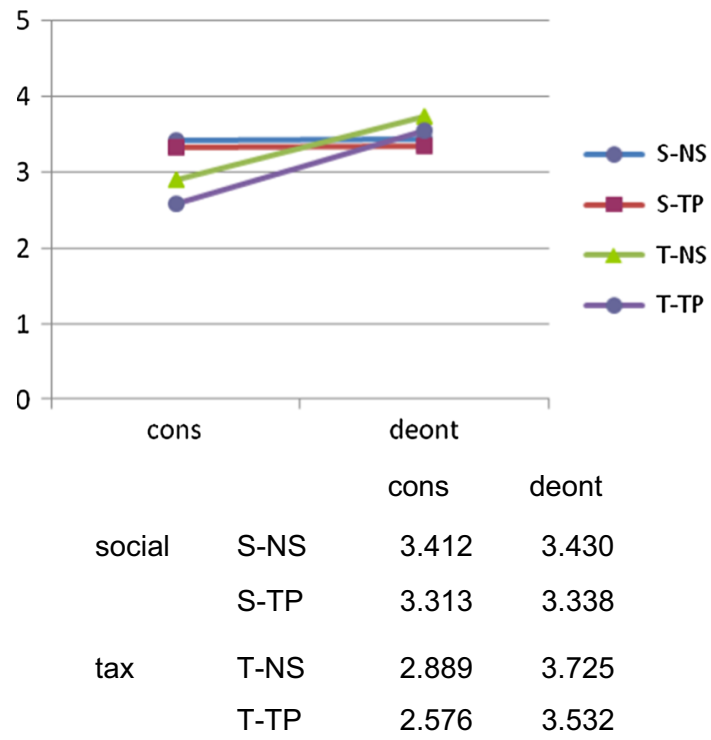

Fig. 3 Average ratings given to consequentialist and deontological items by non-specialists and tax practitioners in the social and tax scenarios for comparison (mean values shown beneath interaction graph)

with the ratio for tax practitioners seeming lower than for non-specialists in this situation (see bottom of Fig. 4 for mean values).

A repeated measures GLM with the consequentialist/ deontological rating ratio in the social and tax context as a repeated measure (CONTEXT) and TAXPRACTITIONER as a between-subjects measure showed that there is a significant difference between the two contexts

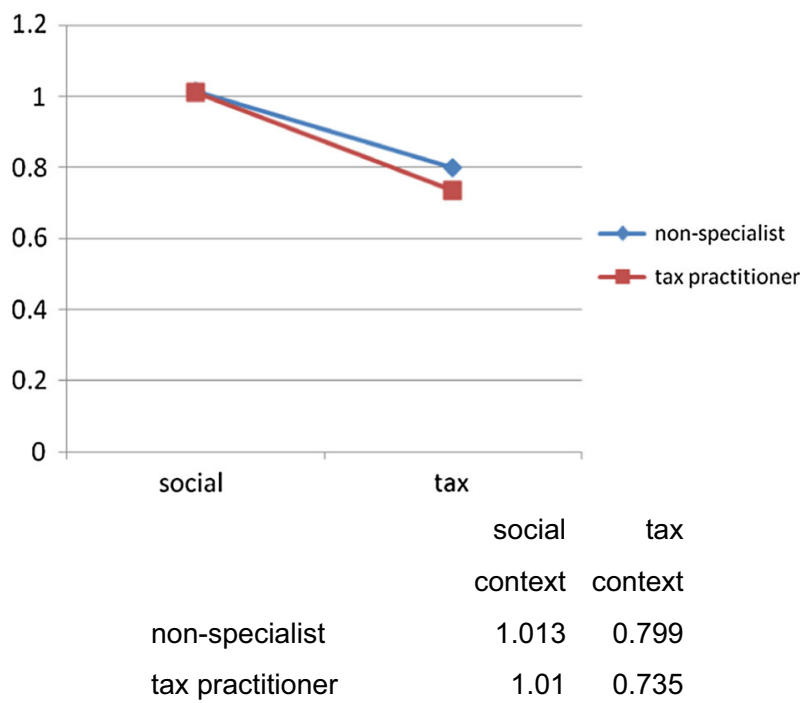

Fig. 4 Consequentialist/deontological rating ratio for non-specialists and tax practitioners in the social and tax scenarios (mean values shown beneath interaction graph)

( $p<0.001)$ but no main effect of TAXPRACTITIONER $(p>0.1)$. There was a significant interaction between CONTEXT and TAXPRACTITIONER $(p=0.038)$, supporting the difference observed between the two groups in the tax but not the social domain. The intuition of the results is shown in Fig. 4 below, and the statistical results are shown in Table 4. As in the analysis above the significant interaction has a considerably smaller effect size than the context. 
Table 4 GLM repeated measures model looking at the impact on importance rating of whether the item rated is consequentialist or deontological, whether the context is social or tax related and whether the participant is a tax practitioner or non-specialist

\begin{tabular}{lllrrr}
\hline & Type III sum of squares & df & $F$ & Sig & Effect size (partial $\left.\eta^{2}\right)$ \\
\hline Within-subjects effects and interactions & & & & & \\
$\quad$ Context (CONTEXT) & 6.000 & 1 & 284.651 & 0.000 & $0.589^{* * *}$ \\
CONTEXT $\times$ TAXPRACTITIONER & 0.092 & 1 & 4.380 & 0.038 & $0.022^{* *}$ \\
Between-subjects effects & & & & 0.131 & 0.011 \\
$\quad$ TAXPRACTITIONER & 0.114 & 1 & 2.294 & 0.13 \\
\hline
\end{tabular}

Significance levels: $* * * \leq 0.01, * * \leq 0.05$

\section{Conclusion}

As was shown by the examples in the section on the different types of tax practitioner work, while sometimes legislation is unclear, the situation to which it applies is frequently also unclear (when is a new chimney on a building a new capital item or a repair?). Not only is interpretation of the law required but often interpretation of the situation to which it applies is also needed.

If the intention of the law is not clear, it is harder for a practitioner to decide the reasonable boundaries of interpretation, and they can easily extend these to include consequentialist considerations that are of benefit to a given client's situation, in extreme cases leading to practitioners feeling that they can justify the promotion and development of an avoidance scheme. As Freedman (2012, p. 650) comments:

there are areas of genuine uncertainty in the tax arena and appeals to morality will not resolve these uncertainties. Not only is there not always an obvious morally right answer to the question of how much tax should be paid, but taxpayers will argue, reasonably, that their liability to pay tax is about the duty imposed on them by law, so that only the law can answer that question. Taxes are not voluntary contributions and therefore there must be a question mark over the extent to which sums not clearly required to be paid by law should be coaxed out of taxpayers by persuasion.

A tax practitioner's desire to comply with the spirit of the law (and thus adopt an approach that is inherently highly ethical) may thus be frustrated by lack of clarity in the spirit or intention of the law itself and/or the situation to which the law is being applied. As exemplified in the Sixth Commandment, cited earlier ("thou shalt not kill"), even something designed to be universally applicable over time may be subject to modifications determined by circumstance. The earlier citation from the 2007 HMRC International Tax Handbook makes clear that the spirit of the law may be less than obvious (and may be what the tax authority itself decides) and that also a given law may need to be applied to situations that were not envisaged when it was drafted. If it is difficult for a tax practitioner acting in good faith to define what the intention of law might be even if he/she wishes to obey it, then there is clearly opportunity for the less principled individual deliberately to exploit that lack of clarity (e.g. by development of 'schemes'). If interpretation is needed, arguably it must be accompanied by a degree of consequentialism relating to the end the practitioner feels the law is trying to attain, where this is not completely defined, and the stance the tax practitioner therefore needs to adopt to meet that end, as a deontological rule-following approach cannot be used. One has to decide what outcomes the spirit of the law was aiming at. In the earlier example cited of whether a new chimney might be a repair or a new capital item, the law inherently assumes that such a distinction would be clear, when in practice it may not be. It is hard to see how consequential considerations can be avoided in this situation, although how these become manifest will depend on the individual's moral compass. One person might form the view that, for tax, the aim could be the collection of the maximum amount that can be argued for, but the CIOT reminds practitioners that "[t]he recent public debate on tax avoidance has not changed the member's responsibility to his client" (Chartered Institute of Taxation (CIOT) (2014, 
p. 38, Section 8.10). Individuals then have to judge what the profession might expect them to provide (aware that legal action against them may follow if they do not meet this expectation), so it is hard to avoid consideration of future consequences. A personal decision may be made on a basis of virtue ethics, but one can argue that the judgement then has consequential aspects, in that there are consequences to knowing one did not act as a virtuous man would have (even if this is only being bothered by one's conscience).

However, this is not to deny that instances where individuals act in overtly consequentialist ways by blatantly serving their own interests, such as by promoting or implementing 'schemes', desiring to satisfy particular types of client, developing a particular type of reputation, etc., are unacceptable, but rather that a consequentialist stance per se is not, we would argue, inherently unethical: in taxation, the situation is more nuanced. However, either interpreting genuinely ambiguous law or using a 'scheme' could present challenges to a revenue authority's preferred stance, which might involve expenditure of time to resolve (and potentially financial expenditure if a court case is involved) for both the practitioner and the revenue authority. On the other hand, producing definitions of tax requirements that are not subject to interpretation can also require time and financial investment (including legal advice). One might therefore expect tax systems to evolve to the most advantageous equilibrium of these two costs from the viewpoint of the government. The extent to which a revenue interpretation is defended in court also contributes to this equilibrium.

Thus, despite the fact that codes of ethics of tax professional bodies show a strong deontological leaning, given the interplay between and weighting of factors that must to be taken into account, and the need for interpretation of law and of the situation to which it is applied, it is not, perhaps, as surprising as it might at first seem that utilitarian or consequentialist factors play some role in ethical decision making. A novel contribution from this study has been to identify both the deontological and the consequentialist factors in the DIT and TPDIT and examine the balance between them in ethical decision making in different contexts.

Our empirical results indicate that both tax practitioners and the control group of non-tax specialists show a more marked deontological orientation in the tax scenarios, while giving more equal weighting to deontological and consequentialist issues in the social scenarios. While the average deontological scores of the non-tax specialists are higher than tax specialists in the tax scenarios, their consequentialist scores are also higher, and inspection of the consequentialist/deontological ratio shows that it is the tax practitioners who are giving a relatively higher weight to deontological items. The move to a higher weighting on deontological items in tax scenarios may reflect a recognition of the fundamentally legal nature of tax, and this could lead to people tending to reason at Kohlberg's Stage 4 (1973), where the focus is on the morality of law and duty to the social order by obedience to defined rules that are of benefit to all; and the links between these results and Kohlberg's Stage Theory are worthy of further investigation. However, although the differences between participant groups are significant statistically, they are not big effects, and the results generally support a similar pattern of response for tax practitioners and non-specialists. While one might expect non-specialists to have less legal focus, tax practitioners still give some weight to consequentialist considerations in tax scenarios, so the dilemmas of interpretation and the weight given to issues outside the immediate transaction are being considered. Thus the current results may reflect the equilibrium of costs mentioned above as determined by this jurisdiction.

Open Access This article is distributed under the terms of the Creative Commons Attribution 4.0 International License (http://crea tivecommons.org/licenses/by/4.0/), which permits unrestricted use, distribution, and reproduction in any medium, provided you give appropriate credit to the original author(s) and the source, provide a link to the Creative Commons license, and indicate if changes were made.

\section{Appendix 1: DIT Scenario One: Heinz and the Drug (Rest 1986a) ${ }^{4}$}

The indication of the stage of moral reasoning represented by each item for consideration below is not present in the instrument used with participants.

In a small European town a woman was near death from a rare kind of cancer. There was one drug that doctors thought might save her. It was a form of radium that a pharmacist in the same town had recently discovered. The drug was expensive to make, but the pharmacist was charging ten times what the drug cost to make. He paid $€ 200$ for the radium and charged $€ 2000$ for a small dose of the drug. The sick woman's husband, Heinz, went to everyone he knew to borrow the money, but he could only get together about $€ 1000$, which is half of what it cost. He told the pharmacist that his wife was dying and asked him to sell it cheaper or let him pay later, but the pharmacist said, "No. I discovered the drug and I'm going to make money from it". So Heinz got desperate and began to think about breaking into the man's store to steal the drug for his wife.

\footnotetext{
${ }^{4}$ The Heinz scenario has been slightly altered from the original Rest (1986b) version in order to update the language slightly for the Irish jurisdiction context used in this study. The original dollar figure mentioned in the scenario has been changed to Euros and the word 'druggist' has been replaced by 'pharmacist'.
} 
Should Heinz steal the drug?

Should steal it

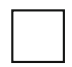

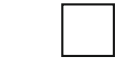

Can't decide
Should not steal it

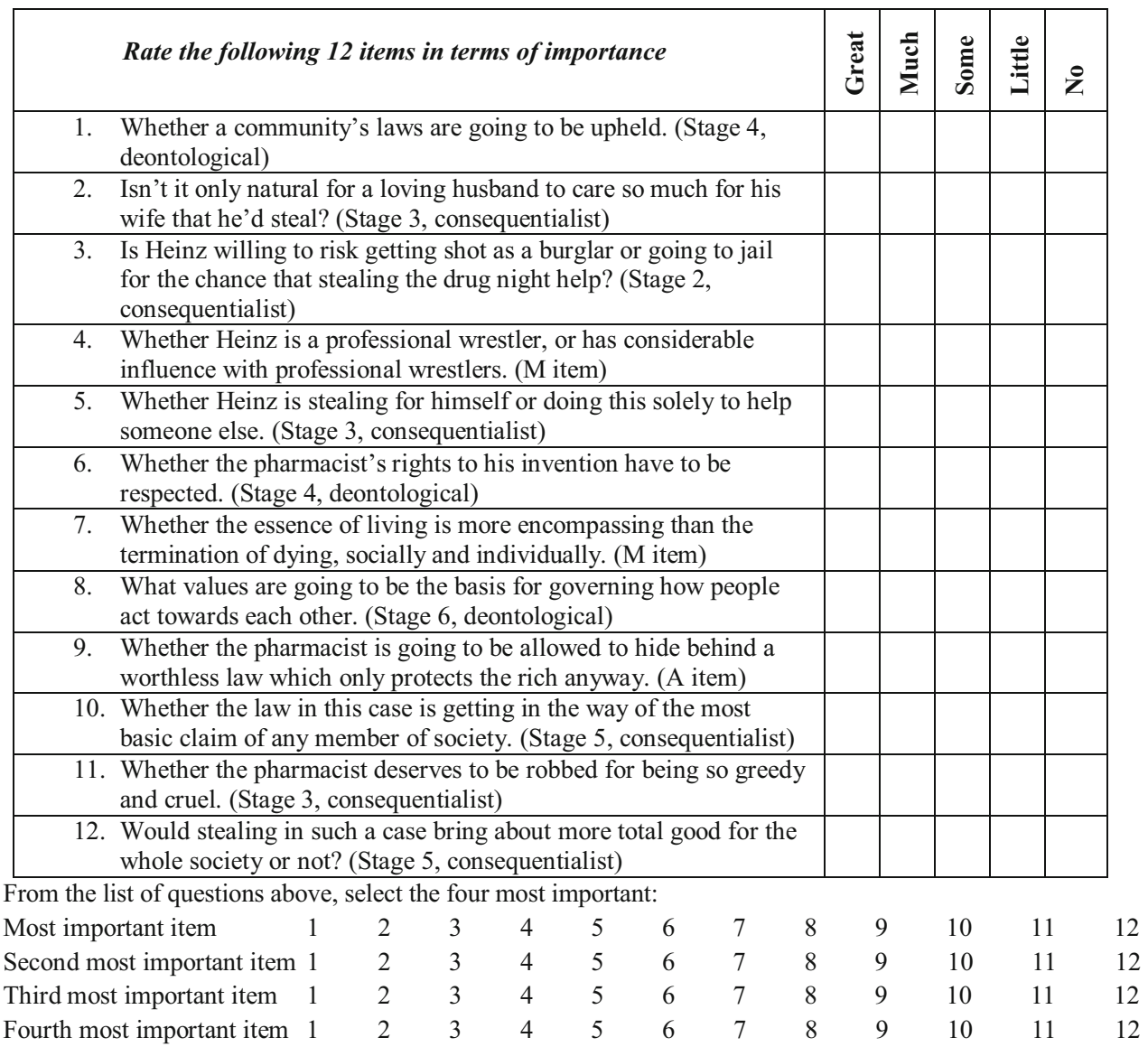

\section{Appendix 2: Tax-DIT Scenario One: Capital Allowances}

Anne is a tax practitioner with an accounting firm. She is working on a capital allowance claim to benefit one of her firm's corporate clients that is in financial distress. Despite profitable trading, the client has suffered severe cashflow problems as a result of adverse economic conditions. The capital allowances claim relates to a new factory building and will significantly reduce taxable corporate profits (and thus the tax the client has to pay). To be eligible for capital allowances the factory has to be in use at the end of the client's financial year. Without the reduction in tax from the capital allowances, it is unlikely that the company will survive, which will result in 5000 employees losing their jobs.

It is now a month since the client's financial year end and Anne has asked the financial controller for documentary evidence that the factory was in use at the end of the financial year. The financial controller sends her a copy of the minutes of the latest directors' board meeting. The last item on the board minutes notes that the factory premises became fully operational on the last day of the financial year. However, Anne is convinced that this was not the case as she drives past the factory every evening and it is clearly unoccupied. However, she also knows that the company will not survive if the capital allowances cannot be claimed. Should Anne file a tax return claiming capital allowances for the financial year? 


\begin{tabular}{|c|c|c|c|c|c|}
\hline Can't decide & & e shc & uldn & & \\
\hline Rate the following 12 items in terms of importance & 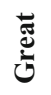 & $\stackrel{\varrho}{\varrho}$ & $\stackrel{\ddot{\Xi}}{\mathscr{B}}$ & 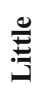 & $\stackrel{\circ}{z}$ \\
\hline $\begin{array}{l}\text { 1. Would it be fair to all the taxpayers who have met the legal } \\
\text { requirements to claim capital allowances if one client is permitted to } \\
\text { claim allowances without meeting the criteria? }\end{array}$ & & & & & \\
\hline $\begin{array}{l}\text { 2. What impact will the company's demise have on the accounting firm } \\
\text { Anne works for? }\end{array}$ & & & & & \\
\hline $\begin{array}{l}\text { 3. Under self-assessment, once Anne has the proper documentation on file } \\
\text { her position is covered regardless of whether the building is actually 'in } \\
\text { use'. }\end{array}$ & & & & & \\
\hline $\begin{array}{l}\text { 4. Whether Anne's notification juxtaposes immediate Revenue authority } \\
\text { cognisant of the client's actions. }\end{array}$ & & & & & \\
\hline 5. Whether Anne and the financial controller are close friends & & & & & \\
\hline 6. Isn't a tax practitioner required to file an accurate tax return? & & & & & \\
\hline 7. Aren't capital allowances the essence of alternative displacement? & & & & & \\
\hline $\begin{array}{l}\text { 8. Which values best determine how tax practitioners should interact with } \\
\text { their clients and engage with the tax legislation? }\end{array}$ & & & & & \\
\hline $\begin{array}{l}\text { 9. Whether a tax system that includes random and meaningless definitions } \\
\text { ought to be completely abandoned. }\end{array}$ & & & & & \\
\hline $\begin{array}{l}\text { 10. Whether the saving of } 5,000 \text { jobs will bring about the best result for } \\
\text { society as a whole. }\end{array}$ & & & & & \\
\hline $\begin{array}{l}\text { 11. Whether the firm's reputation will be damaged if the claim is } \\
\text { subsequently challenged. }\end{array}$ & & & & & \\
\hline $\begin{array}{l}\text { 12. Whether it is socially acceptable for management inadequacies to } \\
\text { deprive employees of their opportunity to earn a living. }\end{array}$ & & & & & \\
\hline
\end{tabular}

From the list of questions above, select the four most important:

\begin{tabular}{|c|c|c|c|c|c|c|c|c|c|c|}
\hline Most important item & 2 & 3 & 4 & 5 & 6 & 7 & 8 & 9 & 10 & 11 \\
\hline Second most important item 1 & 2 & 3 & 4 & 5 & 6 & 7 & 8 & 9 & 10 & 11 \\
\hline Third most important item 1 & 2 & 3 & 4 & 5 & 6 & 7 & 8 & 9 & 10 & 11 \\
\hline Fourth most important item 1 & 2 & 3 & 4 & 5 & 6 & 7 & 8 & 9 & 10 & 11 \\
\hline
\end{tabular}

\section{Table of Statutes}

Great Britain. Finance Act 2004. Elizabeth II. Chapter 12. (2004) London: The Stationery Office.

\section{Table of Cases}

Ayrshire Pullman Motor Services and D. M. Ritchie v CIR (1929) (14 TC 574)

Hurlingham Estates Ltd v Wilde \& Partners [1997] STC 627

IRC v Duke of Westminster [1936] AC 1

Mehjoo v Harben Barker (a firm) \& Anor [2014] EWCA

Civ 358

Revenue Commissioners v O'Flynn Construction \& others [2011] IESC 47

Ramsay (WT) Ltd v CIR [1982] AC 300

\section{References}

Armitstead, L. (2013). Big Four accountants blast tax scheme claims. The Telegraph. Retrieved Aug 18, 2013 from http://www. telegraph.co.uk/finance/personalfinance/consumertips/tax/10018 397/Big-Four-accountants-blast-tax-scheme-claim.

Athanassoulis, N. (2014). Virtue ethics. Internet Encyclopedia of philosophy. Retrieved May 8, 2014 from http://www.iep.utm. edu/virtue/.

Ballas, A. A., \& Tsoukas, H. (1998). Consequences of distrust: The vicious circle of tax evasion in Greece. Paper presented at the European Accounting Association, Antwerp, April.

Bandy, D., Betancourt, L., \& Kelliher, C. (1994). An empirical study of the objectivity of CPAs' tax work. Advances in Taxation, 6 , $1-23$.

Barbour, C., \& McDougall, A. (1997, August 28). Conduct unbecoming. Taxation, pp. 592-595.

Barford, V., \& Holt, G. (2012). Google, Amazon, Starbucks: The rise of 'tax shaming'. Retrieved Dec 29, 2012 from http://www.bbc. co.uk/news/magazine-20560359.

Benshalom, I. (2014). Who should decide whether the apple is rotten? Tax disclosure and corporate political agency. Columbia Journal 
of Tax Law, 6, 86-117. Retrieved May 1, 2015 from SSRN http://ssrn.com/abstract $=2569509$.

Brock, G., \& Russell, H. (2015). Abusive tax avoidance and institutional corruption: The responsibilities of tax professionals, Edmond J. Safra Working Paper No. 56. Retrieved May 10, 2015 from SSRN http://ssrn.com/abstract=2566281 or http://dx.doi. org/10.2139/ssrn.2566281.

Brody, R. G., \& Masselli, J. J. (1996). Tax preparers: Whose team are they on? The National Public Accountant, 41(3), 18-20.

Burns, J. O., \& Kiecker, P. (1995). Tax practitioner ethics: An empirical investigation of organizational consequences. Journal of the American Taxation Association, 17(2), 20-49.

Chartered Institute of Taxation. (2014). Professional conduct in relation to taxation. Retrieved May 6, 2014 from http://www.tax. org.uk/Resources/CIOT/Documents/2014/02/Professional\%20 Conduct\%20in\%20Relation\%20to\%20Taxation\%20190214\%20 final.pdf.

Cloyd, C. B. (1995). The effects of financial accounting conformity on recommendations of tax preparers. Journal of the American Taxation Association, 17(2), 50-70.

Cruz, C. A., Shafer, W. E., \& Strawser, J. R. (2000). A multidimensional analysis of tax practitioners' ethical judgments. Journal of Business Ethics, 24(3), 223-244.

Cuccia, A. D. (1994). The effects of increased sanctions on paid preparers: Integrating economic and psychological factors. Journal of the American Taxation Association, 16(1), 41-66.

Doyle, E., Frecknall-Hughes, J., \& Summers, B. (2009). Research methods in taxation ethics: Developing the defining issues test (DIT) for a tax specific scenario. Journal of Business Ethics, $88(1), 35-52$.

Doyle, E., Frecknall-Hughes, J., \& Summers, B. (2013). An empirical analysis of the ethical reasoning process of tax practitioners. Journal of Business Ethics, 114(2), 325-339.

Doyle, E., Frecknall-Hughes, J., \& Summers, B. (2014). Ethics in tax practice: A study of the effect of practitioner firm size. Journal of Business Ethics, 122(4), 623-641.

Duncan, W. A., LaRue, D. W., \& Reckers, P. M. J. (1989). An empirical examination of the influence of selected economic and noneconomic variables in decision making by tax professionals. Advances in Taxation, 2, 91-106.

Erard, B., \& Feinstein, J. S. (1994). Honesty and evasion in the tax compliance game. Rand Journal of Economics, 25(1), 1-19.

Flew, A. (1979). A dictionary of philosophy. London: Pan Books.

Frecknall-Hughes, J. (2007). The validity of tax avoidance and tax planning: An examination of the evolution of legal opinion. Unpublished LLM dissertation, The University of Northumbria.

Frecknall-Hughes, J. (2014). Locke, Hume and Johnson and the continuing relevance of tax history. eJournal of Tax Research, 12(1), 87-103

Frecknall-Hughes, J., \& McKerchar, M. (2013). Historical perspectives on the emergence of the tax profession: Australia and the UK. Australian Tax Forum, 28(2), 275-288.

Frecknall-Hughes, J., \& Moizer, P. (2015). Assessing the quality of services provided by tax practitioners. eJournal of Tax Research, 13(1), 51-75.

Freedman, J. (2012). Responsive regulation, risk, and rules: Applying the theory to tax practice. UBC Law Review, 44(3), 627-662; Oxford Legal Studies Research Paper No. 13/2012. Retrieved May 9, 2015 from SSRN http://ssrn.com/abstract=2027406.

Fuller, C. (2013). Big Four to appear before Public Accounts Committee. Accountancy Age. Retrieved Aug 18, 2013 from http://www.accountancyage.com/aa/news/2237667/big-four-toappear-before-public-accounts-committee.

Greenfield, A. C., Achilles, W. W., \& Counts, R. W. (2007). The impact of ethical orientation and professional commitment on tax practitioner decision-making performance. Journal of the Academy of Business \& Economics, 7(3), 34-44.

Hammer, S. (1996, January). AICPA statements on responsibilities in tax practice. The CPA Journal, p. 43.

Harwood, R. (1996, August). Ethical training. Accountancy, p. 118.

HMRC. (2013). HMRC's GAAR guidance. Retrieved May 7, 2014 from http://www.hmrc.gov.uk/avoidance/gaar-part-abc.pdf.

Hopkins, J. P. (2014). Loving v. IRS: The IRS's Achilles' heel for regulated tax advice? Virginia Tax Review, 34, 191-228. Retrieved May 6, 2015 from at SSRN http://ssrn.com/abstract= 2547716.

Hunt, S. D., \& Vitell, S. J. (1993). The general theory of marketing ethics: A retrospective and revision. In N. C. Smith \& J. A. Guelch (Eds.), Ethics in marketing (pp. 775-784). Homewood, Illinois: Irwin Publishing.

International Tax Handbook (ITH) 103. (2007). International tax planning: Avoidance in international context. HMRC [Online]. Retrieved Sept 8, 2007 from http://www.hmrc.gov.uk/manuals/ ithmanual/html/ITH0001/02_0007_ITH103.htm.

Irish Taxation Institute. (2014). Code of professional conduct and recommended best practice guidelines. Retrieved Jan 8, 2015 from http://www.taxinstitute.ie/AboutUs/SupportingMembers/ Codeofconduct.aspx.

Jackson, B. R., \& Milliron, V. C. (1989). Tax preparers-government agents or client advocates. Journal of Accountancy, 167(5), 76.

Jackson, B. R., Milliron, V. C., \& Toy, D. R. (1988). Tax practitioners and the government. Tax Notes, 41(3), 333-341.

Kant, I. (1785). Grundlegungzur Metaphysik der Sitten (Fundamental Principles of the Metaphysics of Morals) (J. W. Ellington, Trans.).

Kohlberg, L. (1973). Collected papers on moral development and moral education. Cambridge: Laboratory of Human Development, Harvard University.

Lamont, J., \& Favor, C. (2013). Distributive justice. In Zalta, E. N. (Ed.), Stanford encyclopaedia of philosophy. Retrieved May 5, 2014 fromhttp://plato.stanford.edu/entries/justice-distributive/.

LaRue, D., \& Reckers, P. M. J. (1989). An empirical investigation of the influence of selected factors on professional tax preparers' decision processes. Advances in Accounting, 7, 37-50.

Levy, A. H. (2015). Believing in life after Loving: IRS regulation of tax preparers. Florida Tax Review, 17(5). Retrieved May 5, 2015 from SSRN http://ssrn.com/abstract=2585595.

Locke, J. (1690). The second treatise of government. In P. Laslett (Ed.), Locke's two treatises of government: A critical edition with introduction and notes (Vol. 2). Cambridge: Cambridge University Press.

Longenecker, J. G., McKinney, J. A., \& Moore, C. A. (1989a). The generation gap in business ethics. Business Horizons, 32(5), 9-14.

Longenecker, J. G., McKinney, J. A., \& Moore, C. A. (1989b). Do smaller firms have higher ethics? Business and Society Review, 71(Fall), 19-21.

Mackie, J. L. (1986). Ethics—inventing right and wrong. London: Penguin Books.

Marshall, R. L., Armstrong, R. W., \& Smith, M. (1998). The ethical environment of tax practitioners: Western Australian evidence. Journal of Business Ethics, 17(12), 1265-1279.

McGee, T. C., \& LaTour, M. S. (1991). Taxpayer perceptions of the fairness of the Tax Reform Act of 1986: Do tax preparers and the IRS need to segment their "market"? Journal of Professional Services Marketing, 8(1), 201-221.

Nozick, R. (1974). Distributive justice: The entitlement theory. In T. Honderich \& M. Burnyeat (Eds.), Philosophy it is (pp. 96-130). Harmondsworth, Middlesex, England: Penguin.

Raphael, D. D. (1981). Moral philosophy. Oxford: Oxford University Press. 
Rawls, J. (1971). A theory of justice. Harvard: Harvard University Press.

Rayney, P. (2014). Case report: How the Mehjoo decision affects tax advisers. Retrieved May 5, 2014 from https://www.accountancyl ive.com/case-report-how-mehjooo-decision-affects-tax-advisers.

Reckers, P. M. J., Sanders, D. L., \& Wyndelts, R. W. (1991). An empirical investigation of factors affecting tax practitioner compliance. Journal of the American Taxation Association, 13(2), 30-46.

Rest, J. (1979a). Defining issues test. Minneapolis: University of Minnesota Press.

Rest, J. (1979b). Development in judging moral issues. Minneapolis: University of Minnesota Press.

Rest, J. (1986a). DIT: Manual for the defining issues test. Minneapolis: University of Minnesota Centre for the Study of Ethical Development.

Rest, J. (1986b). Moral development. Advances in research and theory. New York: Praeger Publishers.

Rest, J. (1994). Background: Theory and research. In J. R. Rest \& D. Narvaez (Eds.), Moral development in the professions (pp. 1-26). Hillsdale: Lawrence Erlbaum Associates Inc.

Rest, J., Narvaez, D., Bebeau, M., \& Thoma, S. (1999). Postconventional moral thinking: A neo-Kohlbergian approach. Mahwah: Lawrence Erlbaum Associates.
Roberts, M. R. (1998). Tax accountants' judgment/decision-making research: A review and synthesis. Journal of the American Taxation Association, 20(1), 78-121.

Sanders, D. L., \& Wyndelts, R. W. (1989). An examination of tax practitioners' decisions under uncertainty. Advances in Taxation, 2, 41-72.

Schisler, D. L. (1994). An experimental examination of factors affecting tax preparers' aggressiveness-a prospect theory approach. Journal of the American Taxation Association, 16(2), 124-142.

Schisler, D. L. (1995). Equity, aggressiveness, consensus: A comparison of taxpayers and tax preparers. Accounting Horizons, 9(4), 76-87.

Stainer, A., Stainer, L., \& Segal, A. (1997). The ethics of tax planning. Business Ethics: A European Review, 6(4), 213-219.

Williams, B. (1985). Ethics and the limits of philosophy. London: Fontana Press.

Wyman, P. (1997, January 10). Upholding the law. Tax Journal,, pp. 3-4.

Yetmar, S., \& Eastman, K. (2000). Tax practitioners' ethical sensitivity: A model and empirical examination. Journal of Business Ethics, 26(4), 271-288. 